\title{
Growth hormone treatment of infants with chronic kidney disease: requirement, efficacy, and safety
}

\author{
Dieter Haffner • Dagmar-Christiane Fischer
}

Received: 10 February 2009 / Accepted: 10 February 2009/Published online: 17 April 2009

(C) IPNA 2009

\begin{abstract}
Growth failure is still a challenge in infants suffering from chronic kidney disease (CKD). Persistent growth failure is associated with the excessive mortality rate seen in these patients and markedly hampers later psychosocial integration. Infancy is an extremely sensitive period of growth, since physiological growth rates are several times higher than in later life. Growth failure in infants with $\mathrm{CKD}$ has multiple reasons, originating preferentially from malnutrition and, to a lesser extent, from water and electrolyte losses, metabolic acidosis, anemia, and renal osteodystrophy. Although, recombinant human growth hormone (rhGH) has been proven to be safe and effective for treatment of uremic growth failure in later childhood, its usage has not been adequately investigated in infants. Mencarelli et al. (Pediatric Nephrology 24:10391046, 2009) reported on their retrospective analysis of the longitudinal growth of 27 infants with early onset CKD that were receiving either standard therapy or additional $\mathrm{rhGH}$ treatment. Although their results were encouraging with respect to a sustained catch-up growth in rhGH-treated children, this issue has to be further addressed in prospective randomized controlled trials. In these trials special emphasis has to be given to the safety of this treatment modality, since rhGH might induce insulin resistance and glucose intolerance, especially in infants on high caloric intake and peritoneal dialysis.
\end{abstract}

Remark from the Editors

The article by Mencarelli et al. was published in the May 2009 issue of the Journal and can be found at doi:10.1007/s00467-008-1084-7.

D. Haffner $(\bowtie) \cdot$ D.-C. Fischer

Department of Pediatrics, University Hospital of Rostock,

Rembrandtstr.16/17,

18057 Rostock, Germany

e-mail: dieter.haffner@med.uni-rostock.de
Keywords Infants - Chronic kidney disease - Growth · Treatment · Growth hormone

Growth failure is still a challenge in infants suffering from chronic kidney disease (CKD), and persistent growth failure markedly hampers the later psychosocial integration of these patients. Moreover, the degree of growth retardation is associated with the excessive mortality rate of children with CKD $[1,2]$.

Infancy is an extremely sensitive period of growth, since the physiological growth rates are several times higher than in later life. Approximately one-third of postnatal growth occurs during the first 2 years of life. Therefore, any circumstances diminishing growth rates during the first 2 years bear the inherent risk of subsequent severe growth retardation and the irreversible loss of growth potential. Infants with residual renal function may show only mild decreases in standardized height, whereas, for children with end-stage renal disease (ESRD), the mean decrease in standardized height can be as high as -0.6 standard deviations (SD) per month [3, 4].

Several factors are likely to contribute to growth failure in infants with CKD. Among these are energy malnutrition, catabolic episodes as a result of infection (peritonitis, urinary tract infection), water and electrolyte disturbances, metabolic acidosis, anemia, and renal osteodystrophy [5]. Malnutrition occurs as a consequence of inadequate nutritional intake and, frequently, recurrent vomiting; it usually lasts for longer periods of time and, because of this, appears to be the most important factor in growth failure during infancy. It remains unclear whether disturbances of the somatotropic hormone axis are already important during infancy, although they are known to have a major impact on uremic growth failure during childhood and adolescence [6-8]. The efficacy and safety of treatment with recombinant human 
growth hormone (rhGH) has been proven in short children with CKD who are on conservative or dialysis treatment [9-12]. However, its usefulness in infants with CKD presenting with persistent growth failure remains unclear.

For the pediatric nephrologist taking care of infants with early onset CKD, three major issues have to be considered. Firstly, is rhGH treatment really required to obtain adequate growth? Secondly, is rhGH effective in these infants, and, thirdly, is this treatment safe?

A survey of the recent literature revealed several studies on longitudinal growth in infants with early onset of severe CKD without concomitant rhGH therapy (Table 1). In these retrospective studies, growth in a total of 162 patients with pre-terminal chronic renal failure or requiring dialysis (hemodialysis, peritoneal dialysis) during their first year of life was analyzed [13-18]. Conservative treatment for these patients consisted of metabolic control for acidosis, electrolyte and water losses, secondary hyperparathyroidism/renal

Table 1 Changes in standardized height in infants with early onset CKD on conservative treatment or dialysis with or without concomitant rhGH therapy reported in the literature since 2000 (GFR glomerular filtration rate, $R R T$ renal replacement therapy, $S D S$ standard osteodystrophy (phosphate binders and vitamin D metabolites), and anemia (iron supplements, erythropoietin). In all studies adequate nutritional intake (i.e. at least $100 \%$ of the recommended dietary allowance) was provided. To achieve the latter goal, approximately two-thirds of these patients, especially those on dialysis, required enteric feeding by nasogastric tube or gastrostomy. At first observation, median standardized height was already reduced to -1.8 SD. In three studies involving 42 infants on peritoneal dialysis (PD) a significant increase in standardized height was noted, and median height in these patients improved from $-1.8 \mathrm{SD}$ at baseline to $-1.0 \mathrm{SD}$ after a median observation period of 9 months [14-16]. Noteworthy, approximately two-thirds of the infants included in these studies originated from Finland and suffered from congenital nephrotic syndrome. Therefore, the results obtained in these studies might be biased due to the special treatment protocol established for this specific disease [19]. Nevertheless, in the

deviation score, $R D A$ recommended dietary allowance, $R T X$ renal transplantation, $P D$ peritoneal dialysis, $H D$ hemodialysis, n.a. not applicable)

\begin{tabular}{|c|c|c|c|c|c|c|c|c|}
\hline Study & $\mathrm{rhGH}$ & Number & $\begin{array}{l}\text { Initial age } \\
\text { (years) }\end{array}$ & GFR/mode of RRT & $\begin{array}{l}\text { Initial height } \\
\text { (SDS) }\end{array}$ & $\begin{array}{l}\text { Final height } \\
\text { (SDS) }\end{array}$ & $\begin{array}{l}\text { Study period } \\
\text { (months) }\end{array}$ & $\begin{array}{l}\text { Energy intake } \\
\text { (\% RDA) }\end{array}$ \\
\hline \multirow[t]{4}{*}{ Kari et al. [13] } & No & 25 & 0.2 & $\begin{array}{l}12 \mathrm{ml} / \mathrm{min} \text { per } \\
1.73 \mathrm{~m}^{2}\end{array}$ & -2.3 & -1.9 & 21 & $\geq 100$ \\
\hline & No & 20 & 0.3 & $\begin{array}{l}\text { Conservative until } \\
\text { RTX }\end{array}$ & -1.7 & -2.0 & 18 & $\geq 100$ \\
\hline & No & 13 & 0.1 & $\mathrm{PD} / \mathrm{HD}$ & -2.2 & -2.1 & 6 & $\geq 100$ \\
\hline & No & 23 & 1.4 & $\mathrm{PD} / \mathrm{HD}$ & -1.6 & -1.5 & 6 & $\geq 100$ \\
\hline Ledermann et al. [14] & No & 20 & 0.3 & $\mathrm{PD}$ & -1.8 & $-0.8^{*}$ & 17 & $\geq 100$ \\
\hline Hölttä et al. [15] & No & 10 & 1.0 & $\mathrm{PD}$ & -1.8 & $-1.0 *$ & 9 & 109 \\
\hline Laakkonen et al. [16] & No & 22 & 0.4 & $\mathrm{PD}$ & -1.8 & $-1.3 *$ & 9 & $110-120$ \\
\hline Shroff et al. [17] & No & 18 & 1.0 & HD & -1.6 & -1.6 & 3 & $\geq 100$ \\
\hline Kovalski et al. [18] & No & 11 & 2.8 & HD & -2.9 & -2.9 & 11 & 150 \\
\hline$\sum$ median (range) & No & 162 & $0.4(0.1-2.8)$ & $\begin{array}{l}\text { Conservative/dialysis } \\
(45 / 117)\end{array}$ & $\begin{array}{c}-1.8(-2.9 \\
\text { to }-1.6)\end{array}$ & $\begin{array}{c}-1.6(-2.9 \\
\text { to }-0.8)\end{array}$ & $9(3-21)$ & $\geq 100$ \\
\hline \multirow[t]{2}{*}{ Fine et al. [10] } & Yes & 19 & 1.4 & $\begin{array}{l}29 \mathrm{ml} / \mathrm{min} \text { per } \\
1.73 \mathrm{~m}^{2}\end{array}$ & -3.0 & $-1.1^{*}$ & 24 & n.a. \\
\hline & No & 11 & 1.5 & $\begin{array}{l}23 \mathrm{ml} / \mathrm{min} \text { per } \\
1.73 \mathrm{~m}^{2}\end{array}$ & -2.5 & -2.7 & 24 & n.a. \\
\hline Maxwell and Rees [21] & Yes & 8 & 1.9 & $\begin{array}{l}17 \mathrm{ml} / \mathrm{min} \text { per } \\
1.73 \mathrm{~m}^{2}\end{array}$ & -3.3 & $-2.2^{*}$ & 12 & n.a. \\
\hline \multirow[t]{2}{*}{ Mencarelli et al. [20] } & Yes & 12 & 0.5 & $\begin{array}{l}\text { Conservative/dialysis } \\
(4 / 8)\end{array}$ & -2.0 & $-0.9 *$ & 24 & 110 \\
\hline & No & 15 & 0.5 & $\begin{array}{l}\text { Conservative/dialysis } \\
(13 / 2)\end{array}$ & -1.6 & -1.0 & 24 & 100 \\
\hline \multirow[t]{2}{*}{$\sum$ median (range) } & Yes & 39 & $1.4(0.5-1.9)$ & $\begin{array}{l}\text { Conservative/dialysis } \\
(31 / 8)\end{array}$ & $\begin{array}{c}-3.0(-3.3 \\
\text { to }-2.0)\end{array}$ & $\begin{array}{c}-1.1 *(-2.2 \\
\text { to }-0.9)\end{array}$ & $24(12-24)$ & \\
\hline & No & 26 & $1.0(0.5-1.5)$ & $\begin{array}{l}\text { Conservative/dialysis } \\
(24 / 2)\end{array}$ & $\begin{array}{c}-2.1(-2.5 \\
\text { to }-1.6)\end{array}$ & $\begin{array}{c}-1.9(-2.7 \\
\text { to }-1.0)\end{array}$ & $24(24-24)$ & \\
\hline
\end{tabular}

$* P<0.05$ versus baseline 
remaining studies involving a total of 110 patients with CKD stages IV/V, the degree of stunting remained more or less constant during the study period (median values $-2.0 \mathrm{SD}$ versus $-2.0 \mathrm{SD})[13,17,18]$.

In summary, with these conservative measures, longitudinal growth at the third percentile can be maintained in the majority of infants with severe early onset CKD, without rhGH treatment. However, one should keep in mind that vigorous metabolic control and adequate caloric intake may be sufficient for the infant to gain weight, but it will hardly induce catch-up growth in the majority of infants whose growth is already severely stunted.

Mencarelli et al. reported on their detailed analysis of growth in a cohort of 27 infants with early onset CKD who were receiving either standard therapy $(n=15)$ or additional rhGH treatment $(n=12)$, which was initiated at a mean age of 6 months (Table 1) [20]. This investigation extends two previous reports on rhGH treatment in growth-retarded infants and young children with CKD [10, 21]. Fine et al. reported on a prospectively randomized controlled study involving 30 growth-retarded infants and young children (mean age 1.4 years) with rather preserved renal function [mean glomerular filtration rate (GFR), $25 \mathrm{ml} / \mathrm{min}$ per $1.73 \mathrm{~m}^{2}$ ] [10]. During rhGH therapy, the mean standardized height significantly increased from $-3.0 \mathrm{SD}$ to $-1.1 \mathrm{SD}$ within 24 months (Table 1). In contrast, there was no significant change in standardized height in controls. Unfortunately, no data on caloric intake for those treated with rhGH and those not treated with rhGH were given. Maxwell and Rees reported on the effects of rhGH on eight infants and young children (mean age 1.9 years) with CKD stages III-IV [21]. They observed a significant increase in mean standardized height from $-3.3 \mathrm{SD}$ to $-2.2 \mathrm{SD}$ within 12 months. Again, in that study, data on nutritional intake are missing.

The results presented by Mencarelli et al. might have been biased due to (1) the retrospective analysis of data and (2) the way the control group was generated. In particular, both groups differed significantly with respect to renal function throughout the study period. Despite these limitations, the authors' results are still remarkable. rhGHtreated patients showed a significant increase in standardized weight as well as in standardized height. Mean standardized height increased from $-2.0 \mathrm{SD}$ to $-0.9 \mathrm{SD}$ within 24 months of rhGH therapy. Although a slight increase in standardized weight and standardized height $(-1.6 \mathrm{SD}$ versus $-1.0 \mathrm{SD})$ was noted in controls, this did not reach statistical significance. It has to be emphasized that two-thirds of Mencarelli's patients receiving rhGH were on dialysis. Previous studies on rhGH treatment of school-aged children on dialysis showed rather disappointing results when compared with the results from those on conservative treatment (i.e. mean increase in height of +1.3
SD versus $+0.8 \mathrm{SD}$ within 2 years) [22]. Therefore, the results of the recent study are quite encouraging and extend the previous observation that efficacy of rhGH is best when initiated at a young age (early childhood) [22]. However, this concept has to be proven in adequately powered and designed clinical trials, and it has to be clarified whether pre-emptive rhGH treatment should be initiated for infants prone to develop severe stunting, i.e. rapid crossing of lower percentiles. The latter concept is supposed to accelerate length and weight gain so that the requirements for renal transplantation are achieved earlier [20].

Although in none of the above studies severe side-effects were noted, the number of data are not sufficient to assure the safety of rhGH therapy for infants. The anti-insulinergic properties of rhGH (e.g. induction of post-receptor defect) are well known [23]. It might well be that long-term rhGH treatment, in combination with the forced high caloric intake and the continuous glucose uptake from PD fluid, induces glucose intolerance and overt diabetes. Furthermore, the induction of hyperparathyroidism, albeit transient, has to be considered as well. Of note, this has previously been observed in a group of fast-growing pubertal patients, raising the possibility that hyperparathyroidism reflects rhGH-induced acceleration of growth [24]. In summery, and despite this criticism, the available data on rhGH treatment of infants with early onset of severe CKD are promising and justify the initiation of an adequately designed and powered clinical trial.

\section{References}

1. Furth SL, Hwang W, Yang C, Neu AM, Fivush BA, Powe NR (2002) Growth failure, risk of hospitalization and death for children with end-stage renal disease. Pediatr Nephrol 17:450-455

2. Wong CS, Gipson DS, Gillen DL, Emerson S, Koepsell T, Sherrard DJ, Watkins SL, Stehman-Breen C (2000) Anthropometric measures and risk of death in children with end-stage renal disease. Am J Kidney Dis 36:811-819

3. Seikaly MG, Salhab N, Gipson D, Yiu V, Stablein D (2006) Stature in children with chronic kidney disease: analysis of NAPRTCS database. Pediatr Nephrol 21:793-799

4. Warady BA, Kriley M, Lovell H, Farrell SE, Hellerstein S (1988) Growth and development of infants with end-stage renal disease receiving long-term peritoneal dialysis. J Pediatr 112:714-719

5. Haffner D, Nissel R (2008) Growth and puberty in chronic kidney disease. In: Geary D-F, Schaefer F (eds) Comprehensive pediatric nephrology. Elsevier, Philadelphia, pp 709-732

6. Bereket A, Lang CH, Blethen SL, Kaskel FJ, Stewart C, Wilson TA (1997) Growth hormone treatment in growth retarded children with end stage renal failure: effect on free/dissociable IGF-I levels. J Pediatr Endocrinol Metab 10:197-202

7. Powell DR, Durham SK, Liu F, Baker BK, Lee PD, Watkins SL, Campbell PG, Brewer ED, Hintz RL, Hogg RJ (1998) The insulin-like growth factor axis and growth in children with chronic renal failure: a report of the Southwest Pediatric Nephrology Study Group. J Clin Endocrinol Metab 83:1654-1661 
8. Tönshoff B, Cronin MJ, Reichert M, Haffner D, Wingen AM, Blum WF, Mehls O (1997) Reduced concentration of serum growth hormone $(\mathrm{GH})$-binding protein in children with chronic renal failure: correlation with GH insensitivity. The European Study Group for Nutritional Treatment of Chronic Renal Failure in childhood. The German Study Group for Growth Hormone Treatment in Chronic Renal Failure. J Clin Endocrinol Metab 82:1007-1013

9. Fine RN, Kohaut EC, Brown D, Perlman AJ (1994) Growth after recombinant human growth hormone treatment in children with chronic renal failure: report of a multicenter randomized doubleblind placebo-controlled study. Genentech Cooperative Study Group. J Pediatr 124:374-382

10. Fine RN, Attie KM, Kuntze J, Brown DF, Kohaut EC (1995) Recombinant human growth hormone in infants and young children with chronic renal insufficiency. Genentech Collaborative Study Group. Pediatr Nephrol 9:451-457

11. Haffner D, Schaefer F, Nissel R, Wuhl E, Tonshoff B, Mehls O (2000) Effect of growth hormone treatment on the adult height of children with chronic renal failure. German Study Group for Growth Hormone Treatment in Chronic Renal Failure. N Engl J Med 343:923-930

12. Nissel R, Lindberg A, Mehls O, Haffner D (2008) Factors predicting the near-final height in growth hormone-treated children and adolescents with chronic kidney disease. J Clin Endocrinol Metab 93:1359-1365

13. Kari JA, Gonzalez C, Ledermann SE, Shaw V, Rees L (2000) Outcome and growth of infants with severe chronic renal failure. Kidney Int 57:1681-1687

14. Ledermann SE, Scanes ME, Fernando ON, Duffy PG, Madden SJ, Trompeter RS (2000) Long-term outcome of peritoneal dialysis in infants. J Pediatr 136:24-29
15. Hölttä T, Ronnholm K, Jalanko H, Holmberg C (2000) Clinical outcome of pediatric patients on peritoneal dialysis under adequacy control. Pediatr Nephrol 14:889-897

16. Laakkonen H, Holtta T, Lonnqvist T, Holmberg C, Ronnholm K (2008) Peritoneal dialysis in children under two years of age. Nephrol Dial Transplant 23:1747-1753

17. Shroff R, Wright E, Ledermann S, Hutchinson C, Rees L (2003) Chronic hemodialysis in infants and children under 2 years of age. Pediatr Nephrol 18:378-383

18. Kovalski Y, Cleper R, Krause I, Davidovits M (2007) Hemodialysis in children weighing less than $15 \mathrm{~kg}$ : a single-center experience. Pediatr Nephrol 22:2105-2110

19. Rönnholm KA, Holmberg C (2006) Peritoneal dialysis in infants. Pediatr Nephrol 21:751-756

20. Mencarelli F, Kiepe D, Leozappa G, Stringini G, Cappa M, Emma F (2009) Growth hormone treatment started in the first year of life in infants with chronic renal failure. Pediatr Nephrol 24:1039-1046

21. Maxwell H, Rees L (1996) Recombinant human growth hormone treatment in infants with chronic renal failure. Arch Dis Child 74:40-43

22. Haffner D, Wuhl E, Schaefer F, Nissel R, Tonshoff B, Mehls O (1998) Factors predictive of the short- and long-term efficacy of growth hormone treatment in prepubertal children with chronic renal failure. The German Study Group for Growth Hormone Treatment in Chronic Renal Failure. J Am Soc Nephrol 9:1899-1907

23. Fine RN, Ho M, Tejani A, Blethen S (2003) Adverse events with rhGH treatment of patients with chronic renal insufficiency and end-stage renal disease. J Pediatr 142:539-545

24. Picca S, Cappa M, Martinez C, Moges SI, Osborn J, Perfumo F, Ardissino G, Bonaudo R, Montini G, Rizzoni G (2004) Parathyroid hormone levels in pubertal uremic adolescents treated with growth hormone. Pediatr Nephrol 19:71-76 